\title{
ABOUT SEVERAL NUMERICAL AND SEMIANALYTICAL METHODS OF LOCAL STRUCTURAL ANALYSIS
}

\author{
Pavel A. Akimov 1, 2, 3, 4, Alexander M. Belostotsky 2, 3,4, 5,6, \\ Taymuraz B. Kaytukov ${ }^{1,7}$, Marina L. Mozgaleva ${ }^{8}$, Mojtaba Aslami ${ }^{9}$ \\ ${ }^{1}$ Russian Academy of Architecture and Construction Sciences, Moscow, RUSSIA \\ ${ }^{2}$ Scientific Research Center "StaDyO", Moscow, RUSSIA \\ ${ }^{3}$ Tomsk State University of Architecture and Building, Tomsk, RUSSIA \\ ${ }^{4}$ Peoples' Friendship University of Russia, Moscow, RUSSIA \\ ${ }^{5}$ Russian University of Transport (RUT - MIIT), Moscow, RUSSIA \\ ${ }^{6}$ Perm National Research Polytechnic University, Perm, RUSSIA \\ ${ }^{7}$ Central Institute for Research and Design of the Ministry of Construction and Housing \\ and Communal Services of the Russian Federation, Moscow, RUSSIA \\ ${ }^{8}$ National Research Moscow State University of Civil Engineering, Moscow, RUSSIA \\ ${ }^{9}$ Fasa University, Fasa, IRAN
}

\begin{abstract}
Numerical or semianalytical solution of problems of structural mechanics with immense number of unknowns is time-consuming process. High-accuracy solution at all points of the model is not required normally, it is necessary to find only the most accurate solution in some pre-known domains. The choice of these domains is a priori data with respect to the structure being modelled. Designers usually choose domains with the so-called edge effect (with the risk of significant stresses that could lead to destruction of structures) and regions which are subject to specific operational requirements. Stress-strain state in such domains is important. Wavelets provide effective and popular tool for local structural analysis. Operational and variational formulations of problems of structural mechanics with the use of method of extended domain are presented. After discretization and obtaining of governing equations, problems are transformed to a multilevel space by multilevel wavelet transform. Discrete wavelet basis is used and corresponding direct and inverse algorithms of transformations are performed. Due to special algorithms of averaging, reduction of the problems is provided. Wavelet-based methods allows reducing the size of the problems and obtaining accurate results in selected domains simultaneously. These are rather efficient methods for evaluation of local phenomenon in structures.
\end{abstract}

Keywords: numerical methods, semianalytical methods, local structural analysis, structural mechanics, wavelet-based methods, reduction, operational formulations, variational formulation, boundary problem

\section{О НЕКОТОРЫХ ЧИСЛЕННЫХ И ПОЛУАНАЛИТИЧЕСКИХ МЕТОДАХ ЛОКАЛЬНОГО РАСЧЕТА СТРОИТЕЛЬНЫХ КОНСТРУКЦИЙ}

\footnotetext{
П.А. Акимов ${ }^{1,2,3,4}$, А.М. Белостоцкий ${ }^{2,3,4,5,6}$, Т.Б. Кайтуков ${ }^{1,7}$, М.Л. Мозгалева ${ }^{8}$, М. Аслами ${ }^{9}$

${ }^{1}$ Российская академия архитектуры и строительных наук, г. Москва, РОССИЯ

${ }^{2}$ Научно-исследовательский центр СтаДиО, г. Москва, РОССИЯ

${ }^{3}$ Томский государственный архитектурно-строительный университет, г. Томск, РОССИЯ

${ }^{4}$ Российский университет дружбы народов, г. Москва, РОССИЯ

${ }^{5}$ Российский университет транспорта (МИИТ), г. Москва, РОССИЯ

${ }^{6}$ Пермский национальный исследовательский политехнический университет, г. Пермь, РОССИЯ

${ }^{6}$ Пермский национальный исследовательский политехнический университет, г. Пермь, РОССИЯ

${ }^{7}$ Центральный научно-исследовательский и проектный институт Министерства строительства и жилищно-коммунального хозяйства Российской Федерации, г. Москва, РОССИЯ

${ }^{8}$ Национальный исследовательский Московский государственный строительный университет, г. Москва, РОССИЯ

${ }^{9}$ Университет Фесы, г. Феса, ИРАН
} 


\begin{abstract}
Аннотация: Численное и полуаналитическое (численно-аналитическое) решение краевых задач строительной механики, нередко характеризующих огромным количеством неизвестных, сопряжено с большим объемом вычислительной работы и значительными временными затратами. Как правило, отсутствует необходимость в обеспечении высокой точности решения во всех точках соответствующей вычислительной модели, зачастую имеется потребность в нахождении высокоточного решения в некотором наборе областей (зон) конструкции, расположение которых, как правило, заранее известно (это своего рода априорная оценка). Расчетчики в этом отношении традиционно выбирают зоны так называемого краевого эффекта (потенциально опасные с точки зрения уровня возникающих напряжений, способных повлечь разрушение конструкций), а также зоны, внимание к которым обусловлено, например, разного рода технологической спецификой и т.д. Для указанных областей важнейшим вопросом является достоверное определение напряженно-деформированного состояния. Вейвлет-анализ является исключительно эффективным инструментарием для построения локальных решений соответствующих краевых задач строительной механики. Постановка последних в статье приводится в операторном и вариационном видах на основе использования метода расширенной (стандартной) области. После введения соответствующей аппроксимации реализуется переход от указанных континуальных постановок к дискретным и дискретно-континуальным. Далее реализуется прямое вейвлет-преобразование с привлечением дискретного вейвлет-базиса (заметим, что предложены соответствующие эффективные алгоритмы прямого и обратного вейвлет-преобразования). Разработанные вейвлет-версии методов локального расчета строительных конструкций позволяют с одной стороны значительно сократить вычислительную размерность решаемых задач, а с другой стороны обеспечить высокую точность получаемых результатов в выбранных областях (зонах) строительных конструкций.
\end{abstract}

Ключевые слова: численные методы, полуаналитические методы, локальный расчет строительных конструкций, локальные решения краевых задач, строительная механика, вейвлет-реализации, редукция, операторные постановки задач, вариационные постановки задач, краевая задача

\section{BASIC FORMULAS OF FAST DIRECT AND INVERSE DISCRETE HAAR TRANSFORMS AND AVERAGING}

\subsection{One-dimensional problems}

1.1.1. Algorithms of fast direct and inverse discrete Haar transforms. Let us consider the one-dimensional region

$$
\omega=\{x: a \leq x \leq b\},
$$

where $x$ is coordinate, $a, b$ are lower and upper limits of interval. Let us divide $\omega$ into $(n-1)$ equal parts, where $n=2^{M}, M$ is the number of levels in the Haar basis [1-5]. Coordinates of mesh nodes are

$$
\begin{array}{r}
x_{i}=a+(i-1) h, i=1,2, \ldots, n ; \\
h=(b-a) /(n-1) .
\end{array}
$$

Haar mesh functions are defined by formulas ( $N_{p}$ is the number of Haar functions at level $p)$ :

$$
\begin{gathered}
\psi_{j}^{p}(i)= \\
=\alpha_{p}^{-1}\left\{\begin{array}{l}
1, \quad 2^{p+1}(j-1)<i \leq 2^{p}(2 j-1) \\
-1, \quad 2^{p}(2 j-1)<i \leq 2^{p+1} j \\
0, \quad i \leq 2^{p+1}(j-1) \cup i>2^{p+1} j, \\
i=1,2, \ldots, n, \quad 0 \leq p<M ; \\
\psi_{1}^{M}(i)=\alpha_{M}^{-1}, \quad i=1,2, \ldots, n ;
\end{array}\right. \\
N_{p}=\left\{\begin{array}{l}
n / 2^{p+1}, \quad 0 \leq p<M \\
1, p=M ; \quad \alpha_{p}=\left\{\begin{array}{l}
\sqrt{2^{p+1}}, 0 \leq p<M \\
\sqrt{2^{M}}=\sqrt{n}, p=M .
\end{array}\right.
\end{array}\right.
\end{gathered}
$$

Let $f(i)$ be arbitrary mesh function. Then we have 


$$
\begin{array}{r}
f(i)=\sum_{p=0}^{M} \sum_{j=1}^{N_{p}} v_{j}^{p} \psi_{j}^{p}(i), \\
v_{j}^{p}=\sum_{i=1}^{n} f(i) \psi_{j}^{p}(i), j=1,2, \ldots, N_{p}, \\
p=0,1, \ldots, M,
\end{array}
$$

where $v_{j}^{p}, j=1,2, \ldots, N_{p}, p=0,1, \ldots, M \quad$ are Haar expansion coefficients.

Algorithm of fast direct discrete Haar transform is described below.

$$
u_{j}^{0}=f(j), j=1,2, \ldots, n ; \quad \alpha_{0}=\sqrt{2} .
$$

We have (for all $p=0,1, \ldots, M-1, j=1,2, \ldots, N_{p}$ ):

$$
\begin{aligned}
& v_{j}^{p}=\alpha_{p}^{-1}\left(u_{2 j-1}^{p}-u_{2 j}^{p}\right) ; \\
& u_{j}^{p+1}=u_{2 j-1}^{p}+u_{2 j}^{p} ; \alpha_{p+1}=\sqrt{2} \alpha_{p} ; \\
& \alpha_{M}=\sqrt{n} ; \quad v_{1}^{M}=\alpha_{M}^{-1} u_{1}^{M},
\end{aligned}
$$

where $u_{j}^{p}, j=1,2, \ldots, N_{p}, p=0,1, \ldots, M \quad$ are auxiliary quantities.

Algorithm of fast inverse Haar transform is described below.

$$
\alpha_{M}=\sqrt{n} ; \quad \alpha_{M-1}=\sqrt{n} ; \quad u_{1}^{M}=\alpha_{M}^{-1} v_{1}^{M} .
$$

We have $\left(p=M-1, M-2, \ldots, 0, i=1,2, \ldots, N_{p}\right)$ :

$$
\begin{aligned}
j=[(i+1) / 2] ; \quad z=(-1)^{i+1} ; \\
\quad u_{j}^{p}=\alpha_{p}^{-1} z v_{j}^{p}+u_{j}^{p+1} ; \quad \alpha_{p-1}=\alpha_{p} / \sqrt{2} .
\end{aligned}
$$

Thus,

$$
f(i)=u_{i}^{0}, \quad i=1,2, \ldots, n
$$

1.1.2. Algorithm of averaging. In many cases it is not necessary to obtain global solution in the domain. Local solution for several prescribed subdomains is normally required. If we don't need to find a complete solution we can reduce the number of unknowns without significant loss of accuracy or with a small error in local solutions. It is reasonable to eliminate unknown expansion coefficients of the basis functions with supports substantially distant from the considering area. Algorithm of averaging in one-dimensional case is described below.

Let us assume that it is necessary to make averaging at some level number $q$. For all $p=0,1, \ldots, q$ and $j=1,2, \ldots, N_{p}$ we suppose

$$
\begin{gathered}
\left(D u^{p}\right)_{2 j-1} \approx\left(D u^{p}\right)_{2 j} \approx\left(D \tilde{u}^{p}\right)_{2 j-1}, \\
v_{2 j-1}^{p}=v_{2 j}^{p}, \quad j=1,2, \ldots, N_{p+1}, \\
\tilde{u}_{2 j-1}^{p}=\left(u_{2 j-1}^{p}+u_{2 j}^{p}\right) / 2 ; \\
\left(D \tilde{u}^{p}\right)_{2 j-1}=\left(\tilde{u}_{2 j}^{p}-\tilde{u}_{2 j-1}^{p}\right) /\left(2^{p+1} h\right) ;
\end{gathered}
$$

Then formulas of averaging have the form

$$
\begin{array}{r}
v_{2 j-1}^{p}=v_{2 j}^{p}=\beta v_{j}^{p+1}, \quad j=1,2, \ldots, N_{p+1} ; \\
\beta=1 /(2 \sqrt{2}) .
\end{array}
$$

\subsection{Two-dimensional problems.}

1.2.1. Algorithms of fast direct and inverse discrete Haar transforms. Let us consider the two-dimensional rectangular domain

$$
\omega=\left\{\left(x_{1}, x_{2}\right): 0 \leq x_{1} \leq l_{1}, 0 \leq x_{2} \leq l_{2}\right\},
$$

where $x_{1}, x_{2}$ are coordinates; $l_{1}, l_{2}$ are dimensions along $x_{1}, x_{2}$. Let us divide $\omega$ into $(n-1)$ equal parts along $x_{1}$ and into $(n-1)$ equal parts along $x_{2}$, where $n=2^{M}, M$ is the number of levels in the Haar basis. We have the following formulas for coordinates of mesh nodes:

$$
\begin{aligned}
& x_{1, i}=\left(i_{1}-1\right) h_{1}, i_{1}=1,2, \ldots, n ; \\
& x_{2, i}=\left(i_{2}-1\right) h_{2}, i_{2}=1,2, \ldots, n, \\
& h_{1}=l_{1} /(n-1) ; \quad h_{2}=l_{2} /(n-1) .
\end{aligned}
$$

Haar mesh functions

$$
\begin{aligned}
\psi_{s_{1}, s_{2}, j_{1}, j_{2}}^{p}\left(i_{1}, i_{2}\right), p & =1,2, \ldots, M, \\
& j_{1}, j_{2}=1,2, \ldots, N_{p}, s_{1}, s_{2}=0,1
\end{aligned}
$$


Pavel A. Akimov, Alexander M. Belostosky, Taymuraz B. Kaytukov, Marina L. Mozgaleva, Mojtaba Aslami

(except $s_{1}=s_{2}=0$ ) can be defined by formulas:

$$
\begin{aligned}
& \psi_{s_{1}, s_{2}, j_{1}, j_{2}}^{p}\left(i_{1}, i_{2}\right)= \\
& =\alpha_{p}^{-1}\left\{\begin{array}{l}
(-1)^{k_{1} s_{1}+k_{2} s_{2}}, \\
\bigcap_{q=1}^{2} \bigcup_{k_{q}=0}^{1}\left(\begin{array}{l}
2^{p+1}\left(j_{q}-1+\frac{k_{q}}{2}\right)<i_{q} \wedge \\
i_{q} \leq 2^{p+1}\left(j_{q}-\frac{1}{2}+\frac{k_{q}}{2}\right)
\end{array}\right),
\end{array}\right.
\end{aligned}
$$

0 , in other cases;

$$
\psi_{0,0,1,1}^{M}\left(i_{1}, i_{2}\right)=\alpha_{M}^{-1}
$$

$$
\begin{aligned}
& N_{p}=\left\{\begin{array}{l}
n / 2^{p+1}, 0 \leq p<M \\
1, p=M ;
\end{array}\right. \\
& \qquad \alpha_{p}=\left\{\begin{array}{l}
2^{p+1}, 0 \leq p<M \\
2^{M}=n, p=M .
\end{array}\right.
\end{aligned}
$$

Let $f\left(i_{1}, i_{2}\right)$ be an arbitrary mesh function. Consequently we have

$$
\begin{aligned}
& f\left(i_{1}, i_{2}\right)=v_{0,0,1,1}^{M} \psi_{0,0,1,1}^{M}+ \\
& +\sum_{p=0}^{M-1} \sum_{j_{1}=1}^{N_{p}} \sum_{j_{2}=1}^{N_{p}}\left(v_{1,0, j_{1}, j_{2}}^{p} \psi_{1,0, j_{1}, j_{2}}^{p}\left(i_{1}, i_{2}\right)+\right. \\
& \left.+v_{0,1, j_{1}, j_{2}}^{p} \psi_{0,1, j_{1}, j_{2}}^{p}\left(i_{1}, i_{2}\right)+v_{1,1, j_{1}, j_{2}}^{p} \psi_{1,1, j_{1}, j_{2}}^{p}\left(i_{1}, i_{2}\right)\right),
\end{aligned}
$$

where $v_{1,0, j_{1}, j_{2}}^{p}, v_{0,1, j_{1}, j_{2}}^{p}, v_{1,1, j_{1}, j_{2}}^{p}, j_{1}, j_{2}=1,2, \ldots, N_{p}$, $p=1,2, \ldots, M$ are Haar expansion coefficients,

$$
v_{s_{1}, s_{2}, j_{1}, j_{2}}^{p}=\sum_{i_{1}=1}^{N} \sum_{i_{2}=1}^{N} f\left(i_{1}, i_{2}\right) \psi_{s_{1}, s_{2}, j_{1}, j_{2}}^{p}\left(i_{1}, i_{2}\right) .
$$

Algorithm of fast direct discrete Haar transform is described below.

$$
\begin{array}{r}
u_{j_{1}, j_{2}}^{0}=f\left(j_{1}, j_{2}\right), j_{1}=1,2, \ldots, n, j_{2}=1,2, \ldots, n \\
\alpha_{0}=2
\end{array}
$$

We have (for all $p=0,1, \ldots, M-1$, $j_{1}, j_{2}=0,1, \ldots, N_{p}, \quad s_{1}, s_{2}=0,1 \quad$ (except $\left.s_{1}=s_{2}=0\right)$ ):

$$
\begin{gathered}
z_{1}=(-1)^{s_{1}}, \quad z_{2}=(-1)^{s_{2}} ; \quad \alpha_{p+1}=2 \cdot \alpha_{p} ; \\
v_{s_{1}, s_{2}, j_{1}, j_{2}}^{p}=\alpha_{p}^{-1}\left(u_{2 j_{1}-1,2 j_{2}-1}^{p}+z_{1} u_{2 j_{1}, 2 j_{2}-1}^{p}+\right. \\
\left.+z_{2} u_{2 j_{1}-1,2 j_{2}}^{p}+z_{1} z_{2} u_{2 j_{1}, 2 j_{2}}^{p}\right) \\
u_{j_{1}, j_{2}}^{p+1}=u_{2 j_{1}-1,2 j_{2}-1}^{p}+u_{2 j_{1}, 2 j_{2}-1}^{p}+ \\
+u_{2 j_{1}-1,2 j_{2}}^{p}+u_{2 j_{1}, 2 j_{2}}^{p} \\
\alpha_{M}=n ; \quad v_{0,0,1,1}^{M}=\alpha_{M}^{-1} u_{1,1}^{M}
\end{gathered}
$$

where $u_{j_{1}, j_{2}}^{p}, j_{1}, j_{2}=1,2, \ldots, N_{p}, p=1,2, \ldots, M$ are auxiliary quantities.

Algorithm of fast inverse Haar transform is described below.

$$
\alpha_{M}=n ; \quad \alpha_{M-1}=n ; \quad u_{1,1}^{M}=\alpha_{M}^{-1} v_{0,0,1,1}^{M}
$$

We have $\left(p=M-1, M-2, \ldots, 0, i_{1}, i_{2}=1,2, \ldots, N_{p}\right)$ :

$$
\begin{aligned}
& j_{1}=\left[\left(i_{1}+1\right) / 2\right] ; \quad j_{2}=\left[\left(i_{2}+1\right) / 2\right] ; \\
& \quad z_{1}=(-1)^{i_{1}+1} ; \quad z_{2}=(-1)^{i_{2}+1} ; \alpha_{p-1}=\alpha_{p} / 2 ; \\
& u_{i_{1}, i_{2}}^{p}= \\
& =\alpha_{p}^{-1}\left(z_{1} v_{1,0, j_{1}, j_{2}}^{p}+z_{2} v_{0,1, j_{1}, j_{2}}^{p}+z_{1} z_{2} v_{1,1, j_{1}, j_{2}}^{p}\right)+ \\
& +u_{j_{1}, j_{2}}^{p+1} .
\end{aligned}
$$

Thus,

$$
f\left(i_{1}, i_{2}\right)=u_{i_{1}, i_{2}}^{0}, \quad i_{1}=0,1, \ldots, n, \quad i_{2}=0,1, \ldots, n
$$

1.2.2. Algorithm of averaging. Let us assume that it is necessary to make averaging at level $q$. For all $p=1,2, \ldots, q, \quad j_{1}, j_{2}=1,2, \ldots, N_{p}$, $s_{1}, s_{2}=0,1$ (except $s_{1}=s_{2}=0$ ) we suppose

$$
\begin{aligned}
& \left(D_{1} u^{p}\right)_{2 j_{1}-1,2 j_{2}-1}=\left(D_{1} u^{p}\right)_{2 j_{1}-1,2 j_{2}}= \\
& =\left(D_{1} u^{p}\right)_{2 j_{1}, 2 j_{2}-1}=\left(D_{1} u^{p}\right)_{2 j_{1}, 2 j_{2}} \approx \\
& \approx\left(D_{1} \tilde{u}^{p}\right)_{2 j_{1}-1,2 j_{2}-1} ; \\
& \left(D_{2} u^{p}\right)_{2 j_{1}-1,2 j_{2}-1}=\left(D_{2} u^{p}\right)_{2 j_{1}-1,2 j_{2}}= \\
& =\left(D_{2} u^{p}\right)_{2 j_{1}, 2 j_{2}-1}=\left(D_{2} u^{p}\right)_{2 j_{1}, 2 j_{2}} \approx \\
& \approx\left(D_{2} \tilde{u}^{p}\right)_{2 j_{1}-1,2 j_{2}-1} ;
\end{aligned}
$$




$$
\begin{gathered}
\left(D_{2}^{+} D_{1}^{+} u^{p}\right)_{2 j_{1}-1,2 j_{2}-1}=\left(D_{2}^{+} D_{1}^{+} u^{p}\right)_{2 j_{1}-1,2 j_{2}}= \\
=\left(D_{2}^{+} D_{1}^{+} u^{p}\right)_{2 j_{1}, 2 j_{2}-1}=\left(D_{2}^{+} D_{1}^{+} u^{p}\right)_{2 j_{1}, 2 j_{2}} \approx \\
\approx\left(D_{2}^{+} D_{1}^{+} \tilde{u}^{p}\right)_{2 j_{1}-1,2 j_{2}-1} ; \\
v_{s_{1}, s_{2}, 2 j_{1}-1,2 j_{2}-1}^{p}=v_{s_{1}, s_{2}, 2 j_{1}, 2 j_{2}-1}^{p}= \\
=v_{s_{1}, s_{2}, 2 j_{1}-1,2 j_{2}}^{p}=v_{s_{1}, s_{2}, 2 j_{1}, 2 j_{2}}^{p} ; \\
\tilde{u}_{j_{1}, j_{2}}^{p}=\left(u_{j_{1}, j_{2}}^{p}+u_{j_{1}+1, j_{2}}^{p}+u_{j_{1}, j_{2}+1}^{p}+u_{j_{1}+1, j_{2}+1}^{p}\right) / 4 ; \\
\left(D_{1}^{+} u^{p}\right)_{j_{1}, j_{2}}=\left(u_{j_{1}+1, j_{2}}^{p}-u_{j_{1}, j_{2}}^{p}\right) /\left(2^{p} h\right) ; \\
\left(D_{2}^{+} u^{p}\right)_{j_{1}, j_{2}}=\left(u_{j_{1}, j_{2}+1}^{p}-u_{j_{1}, j_{2}}^{p}\right) /\left(2^{p} h\right) ; \\
\left(T_{1}^{+} u^{p}\right)_{j_{1}, j_{2}}=u_{j_{1}+1, j_{2}}^{p}+u_{j_{1}, j_{2}}^{p} ; \\
\left(T_{2}^{+} u^{p}\right)_{j_{1}, j_{2}}=u_{j_{1}, j_{2}+1}^{p}+u_{j_{1}, j_{2}}^{p} ; \\
D_{1}=0.5 \cdot T_{2}^{+} D_{1}^{+} ; \quad D_{2}=0.5 \cdot T_{1}^{+} D_{2}^{+} .
\end{gathered}
$$

Final formulas of averaging have the form

$$
\begin{aligned}
& v_{1,0,2 j_{1}-1,2 j_{2}-1}^{p}=v_{1,0,2 j_{1}, 2 j_{2}-1}^{p}=v_{1,0,2 j_{1}-1,2 j_{2}}^{p}= \\
& =v_{1,0,2 j_{1}, 2 j_{2}}^{p}=\beta_{1,0} v_{1,0, j_{1}, j_{2}}^{p+1}, j_{1}, j_{2}=1,2, \ldots, N_{p+1} ; \\
& v_{0,1,2 j_{1}-1,2 j_{2}-1}^{p}=v_{0,1,2 j_{1}, 2 j_{2}-1}^{p}=v_{0,1,2 j_{1}-1,2 j_{2}}^{p}= \\
& =v_{0,1,2 j_{1}, 2 j_{2}}^{p}=\beta_{0,1} v_{0,1, j_{1}, j_{2}}^{p+1}, j_{1}, j_{2}=1,2, \ldots, N_{p+1} ; \\
& v_{1,1,2 j_{1}-1,2 j_{2}-1}^{p}=v_{1,1,2 j_{1}, 2 j_{2}-1}^{p}=v_{1,1,2 j_{1}-1,2 j_{2}}^{p}= \\
& =v_{1,1,2 j_{1}, 2 j_{2}}^{p}=\beta_{1,1}^{p} v_{1,1, j_{1}, j_{2}}^{p+1}, j_{1}, j_{2}=1,2, \ldots, N_{p+1} ; \\
& \beta_{1,0}=0.25 ; \quad \beta_{0,1}=0.25 ; \quad \beta_{1,1}=0.125 .
\end{aligned}
$$

\subsection{Three-dimensional problems.}

This most cumbersome case is described in [6].

\section{MULTILEVEL WAVELET-BASED NUMERICAL METHOD OF LOCAL STRUCTURAL ANALYSIS}

\subsection{Formulation of the problem}

Effective qualitative multilevel analysis of local and global stress-strain states of the structure is normally required in various technical problems. As is known, defects and failures are mostly local in nature. However total load- carrying ability of the structure, associated with the condition of limit equilibrium, is determined by the global behavior of the considering project. Therefore corresponding multilevel approach is peculiarly relevant and apparently preferable in all aspects for qualitative and quantitative analysis of calculation data. Wavelet analysis provides effective and popular tool for such researches. After expansion of the solution with the use of local wavelet basis corresponding components are considered at each level of the basis.

In accordance with the method of extended domain [7], the domain $\Omega$, occupied by considering structure, is embordered by extended one $\omega$ of arbitrary shape, particularly elementary. Operational formulation of the problem in domain $\omega$ normally has the form

$$
L u=F,
$$

where $L$ is the operator of boundary problem, which takes into account the boundary conditions; $u$ is the unknown function; $F$ is the given right-side function.

Directly from operational formulation we have variational formulation of the problem:

$$
\Phi(u)=0.5 \cdot(L u, u)-(F, u),
$$

Solution of (41) is the critical point of (40). $(f, g)$ denotes dot product of functions $f$ and $g$.

Discrete formulation of the problem has the form:

$$
A \bar{u}=\bar{f},
$$

where $A=\left\{a_{i, j}\right\}_{i, j=1,2, \ldots, n_{g l}}$ is the difference approximation of operator $L$; $\bar{u}=\left[\begin{array}{llll}u_{1} & u_{2} & \ldots & u_{n_{g l}}\end{array}\right]^{T}$ is the unknown mesh function; $\bar{f}=\left[\begin{array}{llll}f_{1} & f_{2} & \ldots & f_{n_{g l}}\end{array}\right]^{T}$ is the given right-side mesh function; $n_{g l}$ is dimension of problem.

Various methods can be used to form the matrix of the discrete operator. We recommend method 
of basis (local) variations. Its major peculiarities include universality and computer orientation. We can use the following formulas for linear problems:

$$
\begin{aligned}
& a_{i, j}=\left.\Phi\left(\bar{e}^{(i)}+\bar{e}^{(j)}\right)-\Phi\left(\bar{e}^{(i)}\right)-\Phi\left(\bar{e}^{(j)}\right)+\Phi(\overline{0})\right] ; \\
& f_{i}=0.5 \cdot\left[\Phi\left(\bar{e}^{(i)}\right)-\Phi\left(-\bar{e}^{(i)}\right)\right], \\
& \bar{e}^{(i)}=\left[\begin{array}{llll}
e_{1}^{(i)} & e_{2}^{(i)} & \ldots & e_{n_{g l}}^{(i)}
\end{array}\right]^{T}, \quad i=1,2, \ldots, n_{g l} ; \\
& e_{j}^{(i)}=\delta_{i, j}, \quad j=1,2, \ldots n_{g l} ;
\end{aligned}
$$

$\bar{e}^{(i)}, i=1,2, \ldots, n_{g l}$ are basis mesh vectors; $\overline{0}$ is the null function; $\delta_{i, j}$ is the Kronecker delta.

\subsection{Haar-based formulation of the problem}

Let us consider Haar-based formulation of the problem:

$$
\begin{aligned}
\Phi(\bar{u}) & =0.5 \cdot(A \bar{u}, \bar{u})-(f, \bar{u})= \\
& =0.5 \cdot(L Q \bar{v}, Q \bar{v})-(\bar{f}, Q \bar{v})= \\
& =0.5 \cdot\left(Q^{*} L Q \bar{v}, \bar{v}\right)-\left(Q^{*} \bar{f}, \bar{v}\right),
\end{aligned}
$$

where $Q$ is transition matrix consisting from Haar basis vectors, located in rows. Thus,

$$
\widetilde{\Phi}(\bar{v})=0.5 \cdot\left(Q^{*} L Q \bar{v}, \bar{v}\right)-\left(Q^{*} \bar{f}, \bar{v}\right)
$$

where $\bar{v}$ is vector of Haar expansion coefficients of the vector $\bar{u}$. Corresponding operational formulation of the problem has the form

$$
\tilde{L} \bar{v}=\overline{\tilde{f}}, \quad \tilde{L}=Q^{*} L Q ; \quad \tilde{f}=Q^{*} \bar{f} .
$$

Further reduction of the problem is based on the averaging algorithm specified above.

\section{MULTILEVEL WAVELET-BASED SEMIANALYTICAL METHOD OF LOCAL STRUCTURAL ANALYSIS}

The objects of the multilevel wavelet-based semianalytical (discrete-continual) method are structures with piecewise constancy of physical and geometrical parameters in one dimension (it is so-called "basic direction"). Special discretecontinual design model is introduced. It presupposes wavelet approximation of extended domain along non-basic directions, while along the basic direction problem remains continual. Analytical solution is apparently preferable in all aspects for qualitative analysis of calculation data. It allows investigator to consider boundary effects when some components of solution are rapidly varying functions. Due to the abrupt decrease inside of mesh elements in many cases their rate of change can't be adequately considered by conventional numerical methods while analytics enables study. Another feature of the proposing method is the absence of limitations on lengths of structures. Semianalytical formulation are contemporary mathematical models which currently becoming available for computer realization. Resultant multipoint boundary problem after reduction has the form [8-10]

$$
\left\{\begin{array}{c}
\bar{y}^{\prime}=A_{k} \bar{y}+\bar{f}_{k}, \quad x \in\left(x_{k}^{b}, x_{k+1}^{b}\right), \\
k=1, \ldots, n_{k}-1 \\
B_{k}^{-} \bar{y}\left(x_{k}^{b}-0\right)+B_{k}^{+} \bar{y}\left(x_{k}^{b}+0\right)=\bar{g}_{k}^{-}+\bar{g}_{k}^{+}, \\
k=2, \ldots, n_{k}-1 \\
B_{1}^{+} \bar{y}\left(x_{1}^{b}+0\right)+B_{n_{k}}^{-} \bar{y}\left(x_{n_{k}}^{b}-0\right)=\bar{g}_{1}^{+}+\bar{g}_{n_{k}}^{-},
\end{array}\right.
$$

where $x_{k}^{b}=x_{3, k}^{b}, k=1, \ldots, n_{k}$ are coordinates of boundary points; $A_{k}, k=1,2, \ldots, n_{k}-1$ are matrices of constant coefficients of order $n$; $B_{k}^{-}, B_{k}^{+}, k=2, \ldots, n_{k}-1$ and $B_{1}^{+}, B_{n_{k}}^{-}$are matrices of boundary conditions of order $n$ at point $x_{k}^{b} ; \bar{g}_{k}^{-}, \bar{g}_{k}^{+}, k=2, \ldots, n_{k}-1$ and $\bar{g}_{1}^{+}, \bar{g}_{n_{k}}^{-}$ are right-side vectors of boundary conditions at point $x_{k}^{b} ; \bar{y}=\bar{y}(x)=\left[\begin{array}{llll}y_{1}(x) & y_{2}(x) & \ldots & y_{n}(x)\end{array}\right]^{T}$ is the unknown vector function;

$$
\begin{gathered}
\bar{y}^{(1)}=\bar{y}^{(1)}(x)=d \bar{y} / d x ; \\
\bar{f}_{k}=\bar{f}_{k}(x)=\left[\begin{array}{ll}
f_{k, 1}(x) & f_{k, 2}(x) \ldots f_{k, n}(x)
\end{array}\right]^{T}, \\
k=1,2, \ldots, n_{k}-1
\end{gathered}
$$

are right-side vector functions. 
Solution of considering multipoint boundary problem of structural analysis is accentuated by numerous factors. They include boundary effects (stiff systems) and considerable number of differential equations (several thousands). Matrices of coefficients of a system normally have eigenvalues of opposite signs and corresponding Jordan matrices are not diagonal. Method of solution of multipoint boundary problems for systems of ordinary differential equations with piecewise constant coefficients in structural analysis has been developed. Not only does it overcome all difficulties, but its peculiarities also include universality, computer-oriented algorithm, computational stability, optimal conditionality of resultant systems and partial Jordan decomposition of matrix of coefficient, eliminating necessity of calculation of root vectors.

\section{CONCLUSION}

Currently, high-tech work is underway to integrate the developed numerical and semianalytical methods and corresponding algorithms of local structural analysis into the STADYO software package $[19,20]$.

It should be noted that STADYO is the universal software package, which rovides temperature fields, static, stability and dynamic analysis (including response spectra and accelerations definition) as well as fracture mechanics and strength analysis and optimization of arbitrary combined 2-D and 3-D solid, shell, plate and beam mechanical systems by the finite elements, superelement and other modern numerical methods:

- STADYO-FIELD - stationary field (thermoconduction, filtration, fluid flow, etc) problems;

- STADYO-STAT - linear-elastic static stress-strain analysis;

- $\quad$ STADYO-EIG - solving the eigenvalue problems (natural frequencies and modes, loads and forms of buckling);
- STADYO-SEISM - "normative" spectral analysis of seismic responce under exitations, defined by acceleration spectra;

- STADYO-VIBR - evaluation of system stationary vibration parameters;

- STADYO-SPEC - linear spectral (modern superposition) dynamic analysis;

- $\quad$ STADYO-DYN - direct step-by-step integration of dynamic equations;

- STADYO-NFIELD - solving the nonstationary field problems;

- STADYO-FRAC - solving the linear problems of fracture mechanics, including intensivity ratio coefficients and J-integral definitions;

- STADYO-NLIN - solving the nonlinear static and dynamic problems of motion equations (large displacement, plasticity and viscoplasticity of metals, concrete and ground, opening cracks and joints etc.);

- STADYO-WIND - object-oriented code for 3D static and dynamic analysis of typical wind units;

- $\quad$ STADYO-ASTRA - object-oriented cod for 3D static analysis of typical pipe elements (elbows, tees, weld connections, etc);

- STADYO-INTER - object-oriented code for 3D static and dynamic analysis of combined "soilstructure" systems.

\section{REFERENCES}

1. Atashipour S.R., Girhammar U.A., AlEmrani M. Exact Lévy-type Solutions for Bending of Thick Laminated Orthotropic Plates Based on 3-D Elasticity and Shear Deformation Theories. // Computers \& structures, 2017, Vol. 163, pp. 129-15

2. Demirbas M.D. Thermal Stress Analysis of Functionally Graded Plates With Temperature-Dependent Material Properties Using Theory of Elasticity. // Composites Part B: Engineering, 2017. Vol. 131, pp. 100-124.

3. Georgievskii D.V. Constitutive Relations in Multidimensional Isotropic Elasticity and 
Their Restrictions to Subspaces of Lower Dimensions. // Russian Journal of Mathematical Physics, 2017, Vol. 24, No. 3, pp. 322-325.

4. Huo R., Liu W., Wu P., Zhou D. Analytical Solutions for Sandwich Plates Considering Permeation Effect by 3-D Elasticity Theory. // Steel and Composite Structures, 2017, Vol. 25, No. 2, pp. 127-139.

5. Polizzotto C. A Note on the Higher Order Strain and Stress Tensors Within Deformation Gradient Elasticity Theories: Physical Interpretations and Comparisons. // International Journal of Solids and Structures, 2016, Vol. 90, pp. 116-121.

6. Salehipour H., Nahvi H., Shahidi A., Mirdamadi H.R. 3D Elasticity Analytical Solution for Bending of FG Micro/Nanoplates Resting on Elastic Foundation Using Modified Couple Stress Theory. // Applied Mathematical Modelling, 2017, Vol. 47, pp. 174-188.

7. Shaban M., Alibeigloo A. ThreeDimensional Elasticity Solution for Sandwich Panels with Corrugated Cores by Using Energy Method. // Thin-Walled Structures, 2017, Vol. 119, pp. 404-411.

8. Shariyat M., Asemi K. Uniaxial and Biaxial Post-Buckling Behaviors of Longitudinally Graded Rectangular Plates on Elastic Foundations According to the 3D Theory of Elasticity. // Composite Structures, 2016, Vol. 142, pp. 57-70.

9. Song Z., Dai H.-H. On a Consistent FiniteStrain Shell Theory Based on 3-D Nonlinear Elasticity. // International Journal of Solids and Structures, 2016, Vols. 97-98, pp. 137-149.

10. Wang B., Xia K., Wei G.-W. Second Order Method for Solving 3D Elasticity Equations with Complex Interfaces. // Journal of Computational Physics, 2015, Vol. 294, pp. 405-438.

11. Zhou S., Li A., Wang B. A Reformulation of Constitutive Relations in the Strain Gradient Elasticity Theory for Isotropic Materials. // International Journal of Solids and Structures, 2016, Vol. 80, pp. 28-37.
12. Belostotsky A., Kaytukov T., Afanasyeva I., Grosel J. About Contemporary Problems of Numerical Modelling of Unique Structures, Buildings and Facilities. // MATEC Web Conferences, 2017, Vol. 117.

13. Akimov P.A., Mozgaleva M.L., Sidorov V.N. About Verification of DiscreteContinual Finite Element Method of Structural Analysis. Part 2: ThreeDimensional Problems. // Procedia Engineering, 2014, Vol. 91, pp. 14-19.

14. Akimov P.A., Negrozov O.A. About Application of Unstructured Meshes in Discrete-Continual Finite Element Method of Structural Analysis. // International Journal of Applied Engineering Research, 2015, Vol. 10, Number 20, pp. 40824-40829.

15. Akimov P.A., Negrozov O.A. Semianalytical Structural Analysis Based on Combined Application of Finite Element Method and Discrete-continual Finite Element Method Part 2: Three-Dimensional Theory of Elasticity. // Procedia Engineering, 2016, Vol. 153, pp. 16-23.

16. Akimov P.A., Mozgaleva M.L. Method of Extended Domain and General Principles of Mesh Approximation for Boundary Problems of Structural Analysis. // Applied Mechanics and Materials, 2014, Vols. 580583, pp. 2898-2902.

17. Akimov P.A. Correct Discrete-Continual Finite Element Method of Structural Analysis Based on Precise Analytical Solutions of Resulting Multipoint Boundary Problems for Systems of Ordinary Differential Equations. // Applied Mechanics and Materials, 2012, Vols. 204208, pp. 4502-4505.

18. Mozgaleva M.L., Akimov P.A., Mskhalaya Z.I., Kharitonov V.A. About Method of Basis (Local) Variations and its Applications in Structural Analysis. // Procedia Engineering, 2016, Vol. 153, pp. 501-508.

19. Belostotsky A.M., Akimov P.A., Afanasyeva I.N., Kaytukov T.B. Contemporary Problems of Numerical Modelling of Unique Structures and 
Buildings. // International Journal for Computational Civil and Structural Engineering, 2017, Volume 13, Issue 2, pp. 9-34.

20. Belostotsky A.M., Akimov P.A. Nauchnoissledovatelsky tsentr StaDyO. 25 let na fronte chislennogo modelirovaniys [25-th Anniversary of scientific research centre StaDyO]. // International Journal for Computational Civil and Structural Engineering, 2016, Volume 12, Issue 1, pp. 9-34.

\section{СПИСОК ЛИТЕРАТУРЫ}

1. Atashipour S.R., Girhammar U.A., AlEmrani M. Exact Lévy-type Solutions for Bending of Thick Laminated Orthotropic Plates Based on 3-D Elasticity and Shear Deformation Theories. // Computers \& structures, 2017, Vol. 163, pp. 129-15

2. Demirbas M.D. Thermal Stress Analysis of Functionally Graded Plates With Temperature-Dependent Material Properties Using Theory of Elasticity. // Composites Part B: Engineering, 2017. Vol. 131, pp. 100-124.

3. Georgievskii D.V. Constitutive Relations in Multidimensional Isotropic Elasticity and Their Restrictions to Subspaces of Lower Dimensions. // Russian Journal of Mathematical Physics, 2017, Vol. 24, No. 3, pp. 322-325.

4. Huo R., Liu W., Wu P., Zhou D. Analytical Solutions for Sandwich Plates Considering Permeation Effect by 3-D Elasticity Theory. // Steel and Composite Structures, 2017, Vol. 25, No. 2, pp. 127-139.

5. Polizzotto C. A Note on the Higher Order Strain and Stress Tensors Within Deformation Gradient Elasticity Theories: Physical Interpretations and Comparisons. // International Journal of Solids and Structures, 2016, Vol. 90, pp. 116-121.

6. Salehipour H., Nahvi H., Shahidi A., Mirdamadi H.R. 3D Elasticity Analytical
Solution for Bending of FG Micro/Nanoplates Resting on Elastic Foundation Using Modified Couple Stress Theory. // Applied Mathematical Modelling, 2017, Vol. 47, pp. 174-188.

7. Shaban M., Alibeigloo A. ThreeDimensional Elasticity Solution for Sandwich Panels with Corrugated Cores by Using Energy Method. // Thin-Walled Structures, 2017, Vol. 119, pp. 404-411.

8. Shariyat M., Asemi K. Uniaxial and Biaxial Post-Buckling Behaviors of Longitudinally Graded Rectangular Plates on Elastic Foundations According to the 3D Theory of Elasticity. // Composite Structures, 2016, Vol. 142, pp. 57-70.

9. Song Z., Dai H.-H. On a Consistent FiniteStrain Shell Theory Based on 3-D Nonlinear Elasticity. // International Journal of Solids and Structures, 2016, Vols. 97-98, pp. 137-149.

10. Wang B., Xia K., Wei G.-W. Second Order Method for Solving 3D Elasticity Equations with Complex Interfaces. // Journal of Computational Physics, 2015, Vol. 294, pp. 405-438.

11. Zhou S., Li A., Wang B. A Reformulation of Constitutive Relations in the Strain Gradient Elasticity Theory for Isotropic Materials. // International Journal of Solids and Structures, 2016, Vol. 80, pp. 28-37.

12. Belostotsky A., Kaytukov T., Afanasyeva I., Grosel J. About Contemporary Problems of Numerical Modelling of Unique Structures, Buildings and Facilities. // MATEC Web Conferences, 2017, Vol. 117.

13. Akimov P.A., Mozgaleva M.L., Sidorov V.N. About Verification of DiscreteContinual Finite Element Method of Structural Analysis. Part 2: ThreeDimensional Problems. // Procedia Engineering, 2014, Vol. 91, pp. 14-19.

14. Akimov P.A., Negrozov O.A. About Application of Unstructured Meshes in Discrete-Continual Finite Element Method of Structural Analysis. // International Journal of 
Applied Engineering Research, 2015, Vol. 10, Number 20, pp. 40824-40829.

\section{Akimov P.A., Negrozov O.A.}

Semianalytical Structural Analysis Based on Combined Application of Finite Element Method and Discrete-continual Finite Element Method Part 2: Three-Dimensional Theory of Elasticity. // Procedia Engineering, 2016, Vol. 153, pp. 16-23.

16. Akimov P.A., Mozgaleva M.L. Method of Extended Domain and General Principles of Mesh Approximation for Boundary Problems of Structural Analysis. // Applied Mechanics and Materials, 2014, Vols. 580583, pp. 2898-2902.

17. Akimov P.A. Correct Discrete-Continual Finite Element Method of Structural Analysis Based on Precise Analytical Solutions of Resulting Multipoint Boundary Problems for Systems of Ordinary Differential Equations. // Applied Mechanics and Materials, 2012, Vols. 204208, pp. 4502-4505.

18. Mozgaleva M.L., Akimov P.A., Mskhalaya Z.I., Kharitonov V.A. About Method of Basis (Local) Variations and its Applications in Structural Analysis. // Procedia Engineering, 2016, Vol. 153, pp. 501-508.

19. Belostotsky A.M., Akimov P.A., Afanasyeva I.N., Kaytukov T.B. Contemporary Problems of Numerical Modelling of Unique Structures and Buildings. // International Journal for Computational Civil and Structural Engineering, 2017, Volume 13, Issue 2, pp. 9-34.

20. Белостоцкий А.М., Акимов П.А. Научно-исследовательский центр СтаДиО. 25 лет на фронте численного моделирования. // International Journal for Computational Civil and Structural Engineering, 2016, Volume 12, Issue 1, pp. 9-34

Pavel A. Akimov, Full Member of the Russian Academy of Architecture and Construction Sciences, PhD, Professor; Executive Scientific Secretary of Russian
Academy of Architecture and Construction Sciences; Vice-Director for Science Activities, Scientific Research Center "StaDyO"; Professor of Department of Architecture and Construction, Peoples' Friendship University of Russia; Professor of Department of Structural Mechanics, Tomsk State University of Architecture and Building; 24, Ul. Bolshaya Dmitrovka, 107031, Moscow, Russia; phone +7(495) 625-71-63; fax: +7 (495) 650-27-31; E-mail: akimov@ raasn.ru, pavel.akimov@gmail.com.

Alexander M. Belostotsky, Corresponding Member of the Russian Academy of Architecture and Construction Sciences, Professor, Dr.Sc.; Director of Scientific Research Center "StaDyO"; Professor of Department of Structures, Buildings and Facilities, Russian University of Transport» (RUT - MIIT); Professor of Department of Architecture and Construction, Peoples' Friendship University; Professor of Department of Building Structures and Computational Mechanics, Peoples' Friendship University of Russia; office 810, 18, 3yа Ulitsa Yamskogo Polya, Moscow, 125040, Russia; phone +7 (499) 706-88-10; e-mail: amb@ stadyo.ru.

Taymuraz B. Kaytukov, Advisor of of the Russian Academy of Architecture and Construction Sciences, Associated Professor, Ph.D.; Deputy Executive Scientific Secretary of Russian Academy of Architecture and Construction Sciences; Central Institute for Research and Design of the Ministry of Construction and Housing and Communal Services of the Russian Federation 24, Ul. Bolshaya Dmitrovka, 107031, Moscow, Russia; phone +7(495) 625-81-53; fax: +7 (495) 650-27-31; Email: kaytukov@raasn.ru,tkaytukov@gmail.com.

Marina L. Mozgaleva, PhD, Professor, Department of Applied Mathematics, National Research Moscow State University of Civil Engineering, 26, Yaroslavskoe Shosse, Moscow, 129337, Russia;

phone/fax: +7(499) 183-59-94;

E-mail: marina.mozgaleva@gmail.com

Mojtaba Aslami, Ph.D., Associate Professor, Fasa University, Fasa, Iran;

E-mail: aslami.mojtaba@gmail.com

Акимов Павел Алексеевич, академик РААСН, профессор, доктор технических наук; главный ученый секретарь Российской академии архитектуры и строительных наук; заместитель генерального директора по науке ЗАО «Научно-исследовательский центр СтаДиО»; профессор Департамента архитектуры и строительства Российского университета дружбы народов; профессор кафедры строительной механики Томского государственного архитектурно-строительного университета; 107031, г. Москва, ул. Большая Дмитровка, д. 24, стр. 1; 
тел. +7(495) 625-71-63; факс +7 (495) 650-27-31;

Email: akimov@raasn.ru,pavel.akimov@gmail.com.

Белостоцкий Александр Михайлович, членкорреспондент РАACH, профессор, доктор технических наук; генеральный директор ЗАО «Научно-исследовательский центр СтаДиО»; профессор кафедры «Строительные конструкции, здания и сооружения» Российского университета транспорта (МИИТ); профессор Департамента архитектуры и строительства Российского университета дружбы народов; профессор кафедры строительных конструкций и вычислительной механики Пермского национального исследовательского политехнического университета; 125040, Россия, Москва, ул. 3-я Ямского Поля, д.18, офис 810; тел. +7 (499) 706-88-10;

E-mail: amb@stadyo.ru.

Кайтуков Таймураз Батразович, советник РАACH, доцент, кандидат технических наук, заместитель главного ученого секретаря Российской академии архитектуры и строительных наук; Центральный научно-исследовательский и проектный институт Министерства строительства и жилищнокоммунального хозяйства Российской Федерации 107031, г. Москва, ул. Большая Дмитровка, д. 24, стр. 1; тел. +7(495) 625-81-53; факс +7 (495) 650-27-31;

Email: kaytukov@raasn.ru, tkaytukov@gmail.com.

Мозгалева Марина Леонидовна, доцент, доктор технических наук, профессор кафедры прикладной математики, Национальный исследовательский Московский государственный строительный университет (НИУ МГСУ), Россия, 129337, Москва, Ярославское шоссе, д.26, тел./факс: +7(499) 183-59-94, E-mail: marina.mozgaleva@gmail.com.

Моджтаба Аслами, кандидат технических наук; доцент Университета Фесы; Феса, Иран;

E-mail: aslami.mojtaba@gmail.com. 